\title{
Detecting alterations of glucose and lipid components in human serum by near-infrared Raman spectroscopy
}

\author{
Rita de Cássia Fernandes Borges, Ricardo Scarparo Navarro, Hector Enrique Giana, \\ Fernanda Grubisich Tavares, Adriana Barrinha Fernandes, Landulfo Silveira Junior*
}

\begin{abstract}
Introduction: Raman spectroscopy may become a tool for the analysis of glucose and triglycerides in human serum in real time. This study aimed to detect spectral differences in lipid and glucose components of human serum, thus evaluating the feasibility of Raman spectroscopy for diagnostic purposes. Methods: A total of 44 samples of blood serum were collected from volunteers and submitted for clinical blood biochemical analysis. The concentrations of glucose, cholesterol, triglycerides, and low-density and high-density lipoproteins (LDL and HDL) were obtained using standard biochemical assays. Serum samples were placed in Eppendorf tubes $(200 \mu \mathrm{L})$, kept cooled $\left(5^{\circ} \mathrm{C}\right)$ and analyzed with near-infrared Raman spectroscopy ( $830 \mathrm{~nm}, 250 \mathrm{~mW}$, $50 \mathrm{~s}$ accumulation). The mean spectra of serum with normal or altered concentrations of each parameter were compared to determine which Raman bands were related to the differences between these two groups. Results: Differences in peak intensities of altered sera compared to normal ones depended on the parameter under analysis: for glucose, peaks were related to glucose; for lipid compounds the main changes occurred in the peaks related to cholesterol, lipids (mainly triolein) and proteins. Principal Components Analysis discriminated altered glucose, cholesterol and triglycerides from the normal serum based on the differences in the concentration of these compounds. Conclusion: Differences in the peak intensities of selected Raman bands could be seen in normal and altered blood serum samples, and may be employed as a means of diagnosis in clinical analysis.
\end{abstract}

Keywords: Raman spectroscopy, Human serum, Glucose, Lipids, Cholesterol, Triglycerides.

\section{Introduction}

The biochemical composition of blood plasma reflects the metabolic status of tissues and organs, and is largely used by physicians to assess tissue injuries, disorders in the functioning of specific tissues and organs and metabolic imbalances. The interpretation of the blood biochemical profile is complex due to the several mechanisms that control the blood level of various metabolites, and laboratory biochemical assays are commonly performed for detection of abnormalities (Bachorik et al., 2001; Cordova et al., 2009). These include assays for detection of circulating lipid components such as cholesterol, low-density lipoproteins (LDL), high-density lipoproteins (HDL), triglycerides, glucose and glycated hemoglobin, among other markers that are used to detect metabolic syndrome, together with interrelated risk factors of metabolic origin that have been associated with the development of type 2 diabetes mellitus (DM) and atherosclerotic cardiovascular disease (ACVD) (Grundy et al., 2005; National..., 2002; Stone et al., 2013).

ACVD is currently considered a worldwide epidemic, posing a huge challenge for health services around the world. ACVD risk factors have an important role in the development of atherosclerotic disease. However, the progression of atherosclerosis depends on the quantity and type of lipids with potential to accumulate in the artery wall circulating in the bloodstream (Brasil, 2006; Grundy et al., 2005; Stone et al., 2013; Van de Poll et al., 2001). Therefore, accurate quantification of lipoproteins is of great relevance to the evolution and prevention of ACVD.

Diabetes and hypertension, along with dyslipidemia, constitute the main risk factors for ACVD (Grundy et al., 2005; Hinkle and Cheever, 2013; Klein et al., 1996; Stone et al. 2013). These diseases have been responsible for the high incidence of chronic kidney disease (Lago et al., 2007; Wannamethee et al., 2005). DM is directly related to dyslipidemia, which leads to the development of accelerated atherosclerosis and gives rise to macrovascular complications such as myocardial infarction, stroke and peripheral vascular insufficiency, and microvascular complications that lead to retinopathy, nephropathy and neuropathy in patients with DM types 1 and 2 (Knudson et al., 2001). Therefore, early diagnosis at the primary level of health care is an important contributor to prevent these 
morbidities (Grundy et al., 2005; Stone et al., 2013). The best way to reduce the complications associated with changes in blood glucose and cholesterol is to maintain levels of these components at normal concentrations (Aleixo et al., 2007).

Raman spectroscopy has been proposed as a useful technique for analysis of biological material of clinical interest (Hanlon et al., 2000). It is suitable for biochemical analysis because it allows the measurement of vibrational energy of molecules without destruction or removal of tissue, providing quantitative knowledge of molecular composition in situ in real time (Dingari et al., 2012; Hanlon et al., 2000; Römer et al., 1998; Silveira et al., 2002). Since the Raman spectrum is composed of sharp bands with distinct characteristics specific to each molecule, a substance can easily be distinguished by its intrinsic biochemistry (Silveira et al., 2012). The interpretation of Raman spectra can provide information on the structure, concentration and interaction of molecules in their microenvironments without tissue extraction, labels or use of contrast agents, thus having great potential for biochemical studies, providing qualitative and quantitative diagnostic information in vivo (Hanlon et al., 2000). Since this optical technique does not need sample preparation, a small volume of sample is required. In addition, analysis time is short, allowing dynamic monitoring at a low cost (Carey, 1982; Gremlich and Yan, 2001; Guimarães et al., 2006; Hanlon et al., 2000; Movasaghi et al., 2007; Twardowski and Anzenbacher, 1994).

Using Raman spectroscopy as a biochemical method, it has been possible to quantify protein, cholesterol, fat and calcium crystals in in vitro coronary arteries (Römer et al., 1998), to identify pathological changes in neoplastic tissues such as malignant skin cancer (Silveira et al., 2012), and differences in tissue biochemistry such as identification and quantification of proteins and lipids in the atheromatous plaque (Buschman et al., 2001).

Raman spectroscopy can be easily applied to the analysis of biological fluids. Studies on urine have demonstrated identification and quantification, by means of Raman analysis, of selected parameters important for diagnostics of kidney disease (Bispo et al., 2013; Dou et al., 1996; McMurdy and Berger, 2003). Serological analysis aimed at diagnosis of hepatitis $\mathrm{C}$ has also successfully been performed using Raman analysis (Saade et al., 2008). Berger et al. (1997; 1999) determined the feasibility of measuring blood glucose, cholesterol, urea, glucose and other parameters in physiological concentrations using Raman spectroscopy and multivariate regression. Qi and Berger (2007) measured concentrations of
13 parameters such as cholesterol, triglycerides, HDL, LDL, albumin, and creatinine, among others, in clinical blood serum and urine samples using liquid-core optical fiber (LCOF) Raman spectroscopy. They found a highly significant correlation between predicted and reference concentrations. Rohleder et al. (2005) compared mid-infrared and Raman spectroscopy as techniques to quantify total protein, cholesterol, HDL and LDL, triglycerides, glucose, urea and uric acid in human serum. Shao et al. (2012) demonstrated a high correlation between blood concentrations of glucose measured in vivo in a mouse model by means of Raman spectroscopy and a standard glucose assay method. These studies have confirmed the feasibility of the Raman technique as a non-destructive and effective method for the analysis of biological fluids.

This in vitro study aimed to evaluate the feasibility of a dispersive Raman spectroscopy technique to identify the spectral differences in human blood serum sampled with normal and altered concentrations of the main biochemical components of interest in clinical analysis - glucose, total cholesterol, triglycerides, low-density and high-density lipoproteins - in terms of differences in the intensity of specific Raman peaks related to the concentration of these compounds in each group. Principal Components Analysis (PCA) was used to discriminate between normal and altered serum. The ultimate goal was to evaluate the possibility of the use of Raman spectra as a tool for qualitative and quantitative evaluation of blood biochemistry using a single spectrum, reduced amounts of biological material, and without use of reagents for a rapid screening in clinical analysis.

\section{Methods}

This research was carried out according to ethical principles and regulatory norms for research involving humans (Resolution no. 196/1996, Brazilian Health Council, Ministry of Health). It was approved by the Research Ethics Committee of the Camilo Castelo Branco University (São José dos Campos, SP, Brazil) (Process no. 315993, 25/June/2013, CAAE no. 16464913400005494).

\section{Serum samples}

Human serum samples were obtained from patients whose physician had prescribed clinical laboratory evaluation and routine biochemical assay of glucose and lipids. The clinical analysis laboratory (Laboratório Oswaldo Cruz, São José dos Campos, $\mathrm{SP}$, Brazil) randomly selected blood serum samples from 44 patients. Five biochemical components of the serum were measured: glucose (GLU), total cholesterol 
(CHL), triglycerides (TRG), low-density lipoproteins (LDL) and high-density lipoproteins (HDL). After biochemical evaluation, serum samples were placed in $200 \mu \mathrm{L}$ Eppendorf tubes, kept cooled $\left(5^{\circ} \mathrm{C}\right)$ and analyzed using Raman spectroscopy on the same day as serum collection.

Concentrations of GLU, TRG and HDL were obtained using a COBAS 6000 Analyzer (Roche/ Hitachi, Indianapolis, IN, USA), and concentrations of CHL were obtained using a COBAS INTEGRA 400 PlusAnalyzer and a COBAS INTEGRA 800 Analyzer (Roche/Hitachi, Indianapolis, IN, USA). The LDL was calculated using the Friedewald equation: $\mathrm{LDL}=\mathrm{CHL}$ - HDL - TRG/5 (Fukuyama et al., 2008). In patients with hypertriglyceridemia (TRG $>400 \mathrm{mg} / \mathrm{dL}$ ) the LDL was measured directly in the plasma, given the inaccuracy of the equation for this case.

\section{Raman spectroscopy}

Raman spectra of the serum samples were measured by a trained researcher at controlled room temperature $\left(24{ }^{\circ} \mathrm{C}\right)$ and humidity $(60 \%)$ and following infection control biosecurity rules. Serum samples were placed in an aluminum sample holder with wells of about $100 \mu \mathrm{L}$.

A near-infrared dispersive Raman spectrometer (Dimension P-1 Raman system, Lambda Solutions, Inc., MA, USA) was used, composed of a diode laser $(830 \mathrm{~nm}, 250 \mathrm{~mW})$ for excitation, a compact spectrometer (f\#1/8, 1200 lines $/ \mathrm{mm}$ ) for light dispersion, and a CCD (charge-coupled device) camera (deep-depleted, back-thinned, $1320 \times 100$ pixels, $-75{ }^{\circ} \mathrm{C}$ Peltier-cooled) for converting the optical signal into an electrical signal for further processing, resulting in a resolution of about $2 \mathrm{~cm}^{-1}$ in the center of the spectrum. The spectrometer used a fiber optic Raman probe for excitation and collection of Raman scattering. The Raman spectrometer was configured to perform ten accumulations of $5 \mathrm{~s}$ for each sample (total acquisition time of $50 \mathrm{~s}$ ) using a proprietary software (RamanSoft v. 1.4, Lambda Solutions Inc., MA, USA).
The use of a Raman probe and a sample holder ensured repeatable geometry for excitation and collection of the backscattered Raman signal.

Before data acquisition the spectrometer was calibrated using a standard spectral irradiance lamp and the known Raman shifts of naphthalene. Unwanted background fluorescence was further removed with a seventh-order polynomial function fitted over the $400-1800 \mathrm{~cm}^{-1}$ region and subtracted from the raw spectrum. This procedure allows the Raman bands being observed without interference from unwanted background fluorescence, as well as providing an effective baseline correction. Prior data analysis, the spectra were normalized by the area under the curve.

Three spectral measurements were obtained from each sample (totaling 132 spectra for 44 samples). Spectra were categorized into normal or altered according to the concentrations of each parameter (GLU, CHL, TRG, HDL and LDL; Table 1). Some samples were not fully assessed during serum assay, so the total number of samples for a particular parameter may be lower than the total number of samples. The normalized mean spectrum of normal or altered serum for each biochemical compound was plotted and the $t$-test $(p<0.05$, Instat 3.0 software, GraphPad Software Inc., CA, USA) was used to determine which Raman bands could be used to differentiate between the groups by comparing the means of the peaks of normal and altered groups.

\section{Principal Components Analysis}

A model based on PCA was developed to extract spectral features from the Raman spectra of sera and Euclidean distance (Ciaccio et al., 1994) for discrimination between groups (Silveira et al., 2012), aiming to use Raman spectra to discriminate the data into normal or altered groups based on biochemical profiles of the serum samples. Normalized spectra were analyzed by PCA (princomp.m routine, Matlab 7.4, Statistics Toolbox) and the principal components

Table 1. Reference values established for glucose and lipids on human blood serum, according to the American Heart Association (Stone et al., 2013), number of samples and range of concentrations of components in normal and altered groups.

\begin{tabular}{|c|c|c|c|c|}
\hline $\begin{array}{l}\text { Blood serum } \\
\text { component }\end{array}$ & $\begin{array}{l}\text { Reference values } \\
\qquad(\mathrm{mg} / \mathrm{dL})\end{array}$ & $\begin{array}{l}\text { Number of samples } \\
\text { with normal } \\
\text { concentration [range } \\
\text { of concentrations } \\
(\mathrm{mg} / \mathrm{dL})]\end{array}$ & $\begin{array}{c}\text { Number of samples } \\
\text { with altered } \\
\text { concentration [range } \\
\text { of concentration } \\
(\mathrm{mg} / \mathrm{dL})]\end{array}$ & $\begin{array}{c}\text { Total number of } \\
\text { samples }\end{array}$ \\
\hline Glucose & $70-99$ & 26 [77-97] & 18 [100-328] & 44 \\
\hline Total cholesterol & $<200$ & 11 [112-189] & 31 [201-363] & 42 \\
\hline Triglycerides & $<150$ & 12 [44-142] & 31 [163-1162] & 43 \\
\hline HDL & $40-60$ & 23 [41-138*] & 19 [22-39] & 42 \\
\hline LDL & $<100$ & 20 [54-159] & 13 [167-231] & 33 \\
\hline
\end{tabular}

*for HDL, any concentration greater than $40 \mathrm{mg} / \mathrm{dL}$ was considered normal. 
loading vectors (LVs) and scores (PCs) with statistically significant differences between the means of the two groups, evaluated by the $t$-test, were plotted and the Euclidean distance calculated.

\section{Results}

\section{Raman spectra of human serum}

Figure 1 presents the mean spectrum of all samples of human serum in the spectral range $400-1800 \mathrm{~cm}^{-1}$. This spectrum shows prominent Raman peaks related to proteins in the serum, mainly albumin and globulin (Movasaghi et al., 2007). The labeled peaks in Figure 1 indicate bands with differences in intensity between normal and altered groups. The most intense peaks can be attributed thus: $1004 \mathrm{~cm}^{-1}$ - aromatic ring of phenylalanine (proteins); $1319 \mathrm{~cm}^{-1}$ - amide III (proteins) and $\mathrm{CH}_{3}, \mathrm{CH}_{2}$ wagging (lipids); $1343 \mathrm{~cm}^{-1}$ $\mathrm{CH}_{3}, \mathrm{CH}_{2}$ wagging (lipids/proteins), $1451 \mathrm{~cm}^{-1}-\mathrm{CH}_{3}$, $\mathrm{CH}_{2}$ bending modes (lipids/proteins); and $1659 \mathrm{~cm}^{-1}$ - $\mathrm{C}=\mathrm{O}$ stretching of amide I (proteins) (Berger et al., 1997; Movasaghi et al., 2007; Rohleder et al., 2005).

\section{Evaluation of the glycemic profile}

Figure 2 presents the normalized mean spectra of samples with normal or altered glucose concentrations, as well as the difference between altered and normal spectra. The peaks at 507, 1065 and $1128 \mathrm{~cm}^{-1}$ can be attributed in part to glucose overlapped with protein and lipid bands of the serum (Barman et al., 2012; Berger et al., 1997; Dingari et al., 2011; Saade et al., 2012; Shao et al., 2012). A small spectral difference was observed between the groups. The labeled peaks $\left(507,1065\right.$ and $\left.1128 \mathrm{~cm}^{-1}\right)$ presented statistically significant differences between the groups ( $t$-test, $p<0.05$ ).

\section{Evaluation of lipid profile (cholesterol, triglycerides, $\mathrm{HDL}, \mathrm{LDL}$ )}

The main differences in normal or altered spectra for total cholesterol occurred in peaks at 428, 700, $881,1085,1042,1451$, and $1659 \mathrm{~cm}^{-1}$ ( $t$-test, $p<0.05$; Figure 3). These peaks are related to the spectrum of pure cholesterol (Berger et al., 1999; Gremlich and Yan, 2001; Hanlon et al., 2000; Krafft et al., 2005; Movasaghi et al., 2007).

The main differences in spectra for normal or altered concentrations of triglycerides occurred in peaks at $877,1085,1271,1307$, and $1451 \mathrm{~cm}^{-1}$ $(t$-test, $p<0.05$; Figure 4$)$. These peaks are related to saturated and unsaturated fatty acids (Buschman et al., 2001; Komachi et al., 2006; Krafft et al., 2005; Movasaghi et al., 2007; Van de Poll et al., 2001), particularly triolein (Silveira et al., 2012).

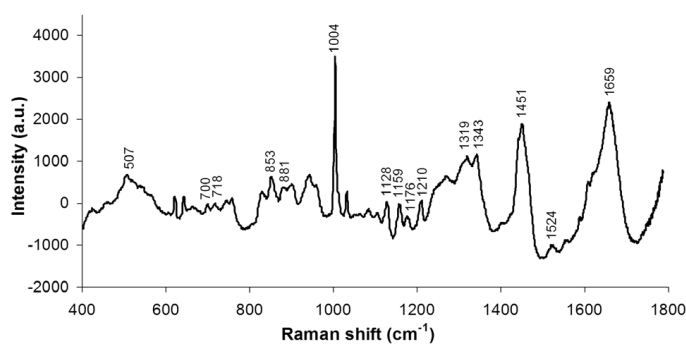

Figure 1. Mean spectrum of all 44 samples of human serum, taken from samples with different concentrations of the serum parameters glucose, cholesterol, triglycerides, HDL and LDL.

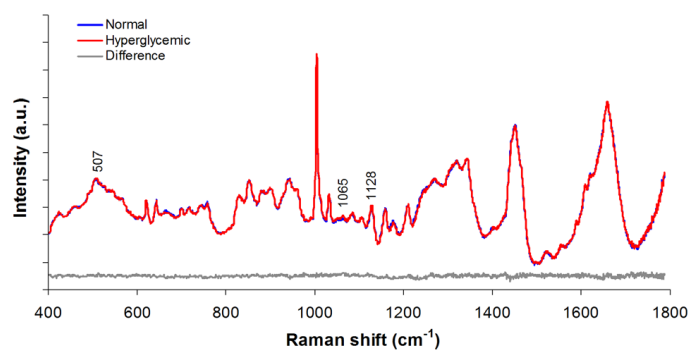

Figure 2. Normalized mean spectra of 44 samples of human serum with normal or altered concentrations of glucose and the difference between the spectra. Labeled peaks are statistically different ( $t$-test, $p<0.05)$ and are in the same positions as pure glucose.

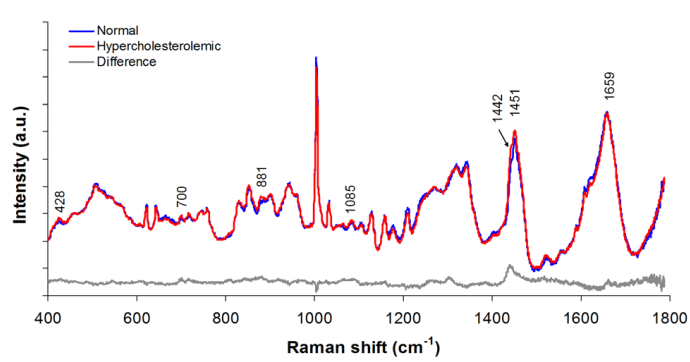

Figure 3. Normalized mean spectra of 42 samples of human serum with normal or altered concentrations of cholesterol, and the difference between them. Labeled peaks represent statistically significant differences between the groups $(t$-test, $p<0.05)$ and are in the same positions as pure cholesterol.

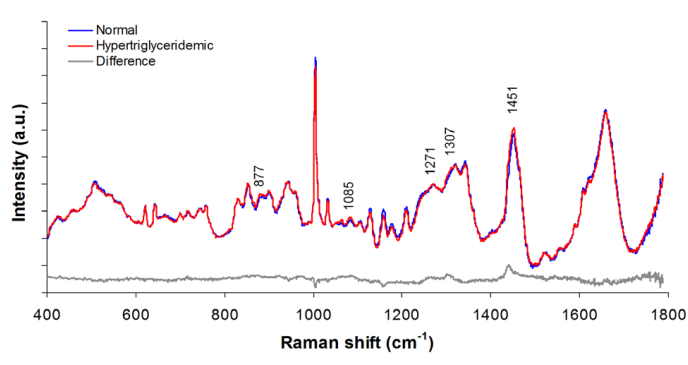

Figure 4. Normalized mean spectra of 43 samples of human serum with normal or altered concentrations of triglycerides, and the difference between them. Labeled peaks represent statistically significant differences between groups ( $t$-test, $p<0.05)$ and are in the same positions as pure triolein. 


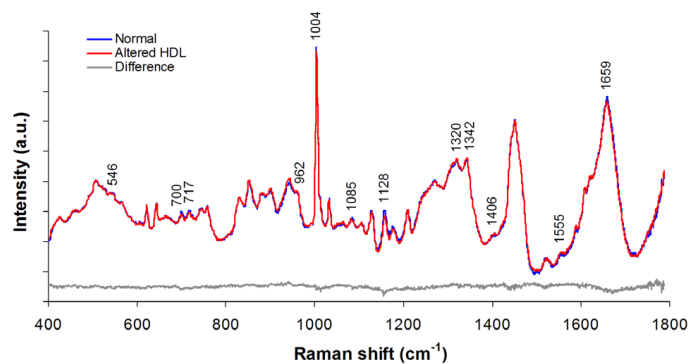

Figure 5. Mean spectra of 42 samples of human serum with normal or altered concentrations of HDL, and the difference between the spectra. Labeled peaks represent statistically significant differences between groups $(t$-test, $p<0.05)$ and are in the same positions as proteins and lipids characteristic of HDL.

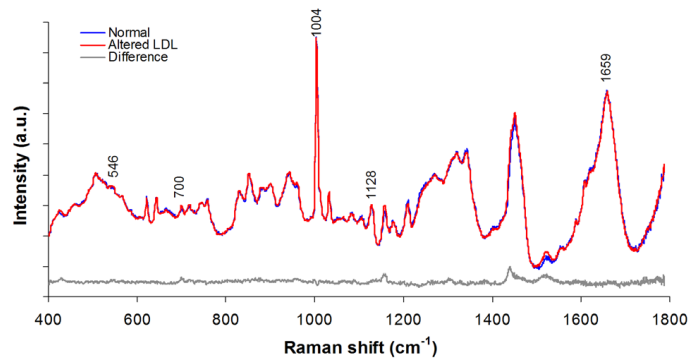

Figure 6. Normalized mean spectra of 33 samples of human serum with normal or altered concentrations of LDL, and the difference between them. Labeled peaks represent statistically significant differences between groups $(t$-test, $p<0.05)$ and are in the same positions as proteins and lipids characteristic of LDL.
The main differences in the spectra of HDL between normal and altered samples occurred in the peaks related to lipids and proteins (Movasaghi et al., 2007). The peaks at 546, 700, 717, 962, 1004, 1085, $1128,1320,1342,1406,1555$, and $1659 \mathrm{~cm}^{-1}$ had significantly lower intensity in the altered group than the normal group, indicative of the lower concentration of HDL in these samples ( $t$-test, $p<0.05$; Figure 5). The main differences in spectra between normal and altered groups for LDL occurred in the peaks at 546, $700,1004,1128$, and $1659 \mathrm{~cm}^{-1}$ (t-test, $p<0.05$; Figure 6), indicative of higher concentrations of proteins and lipids characteristic of LDL molecules (Movasaghi et al., 2007).

\section{Discrimination model based on PCA}

Figure 7 presents a model based on PCA and Euclidean distance for discrimination aiming to use the spectral differences to discriminate the data into groups with normal or altered concentrations of the measured serum parameters. Table 2 presents the number of spectra correctly classified by the PCA and Euclidean distance in each group. Glucose, cholesterol, and triglycerides had high discrimination capability $(>70 \%$ ), with triglycerides most able to discriminate between groups $(81 \%)$, whereas HDL and LDL had low discrimination capability $(<60 \%)$.
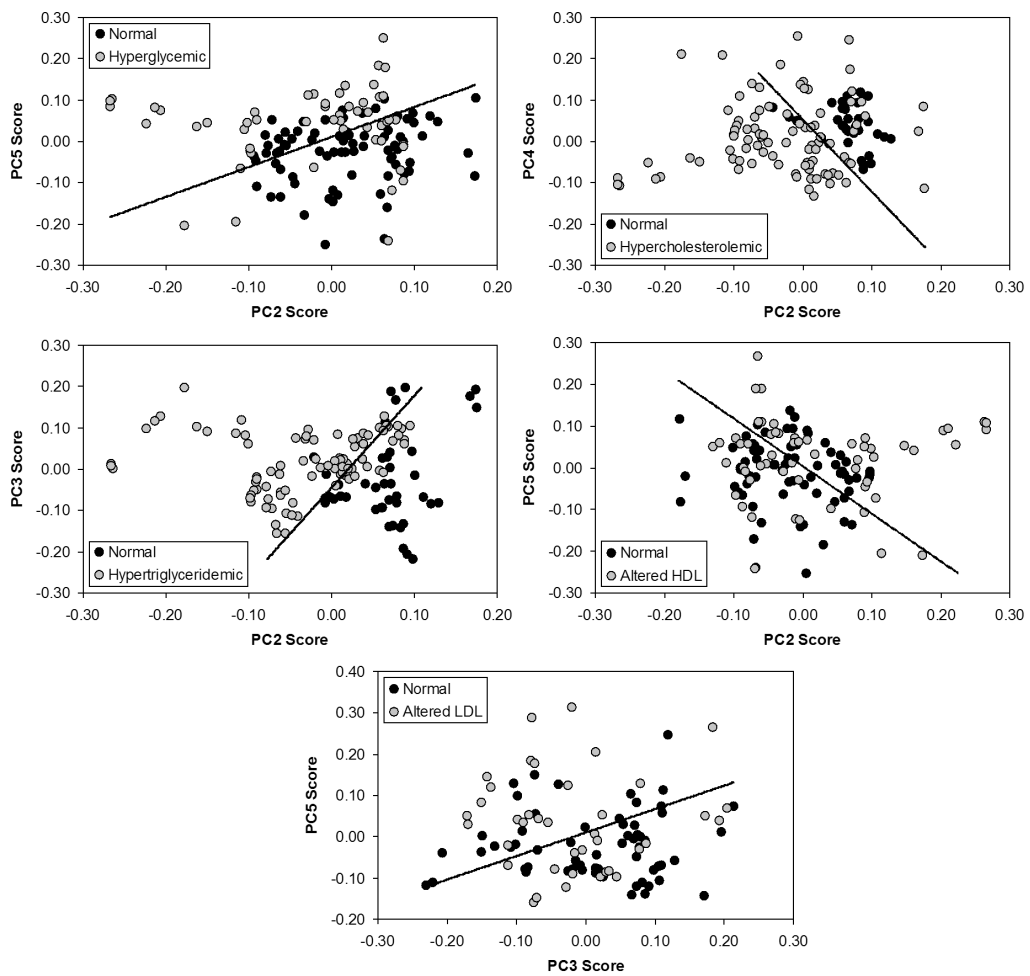

Figure 7. Binary scatter plot of the principal components scores with higher significance for separating the spectra used in the study into normal or altered concentrations of the respective parameters. Spectra are in triplicate. 
Table 2. Number of spectra in each group correctly classified by PCA and Euclidean distance. Spectra are in triplicate.

\begin{tabular}{lccc}
\hline Component & $\begin{array}{c}\text { Number of normal spectra } \\
\text { classified in the normal } \\
\text { group/number in the } \\
\text { normal group }\end{array}$ & $\begin{array}{c}\text { Number of altered spectra } \\
\text { classified in the altered } \\
\text { group/number in the } \\
\text { altered group }\end{array}$ & $\begin{array}{c}\text { Percent correct } \\
\text { classification }\end{array}$ \\
\hline Glucose & $54 / 78$ & $38 / 54$ & $70 \%$ \\
Total cholesterol & $30 / 33$ & $67 / 93$ & $77 \%$ \\
Triglycerides & $30 / 36$ & $74 / 93$ & $81 \%$ \\
HDL & $43 / 69$ & $32 / 57$ & $59 \%$ \\
LDL & $39 / 60$ & $20 / 39$ & $60 \%$ \\
\hline
\end{tabular}

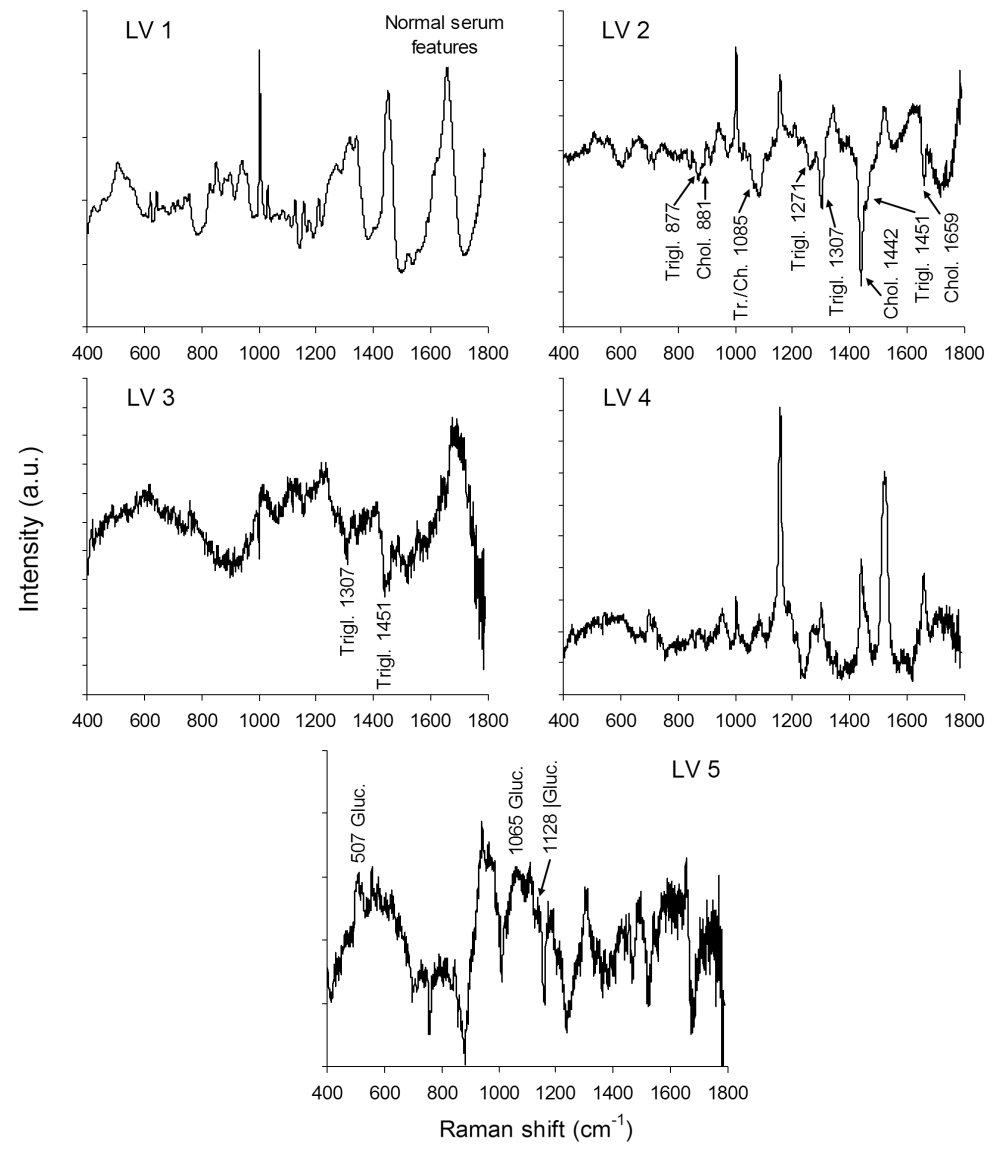

Figure 8. Plot of the first five PCA loading vectors (LV) with positive as well as negative peaks in the same positions of the indicated biochemical elements. LV2, LV3 and LV5 present the most important features to discriminate the normal and altered groups.

Figure 8 plots the first five principal components loading vectors. These vectors present spectral features (positive as well as negative peaks) in the same positions of the main biochemicals responsible for the spectral differences between normal and altered groups. It can be observed that LV1 present spectral features of normal serum, LV2, LV3 and LV5 present spectral features of glucose (LV5), triglycerides (LV2 and LV3) and cholesterol (LV2), matching with the principal components scores that are used to discriminate normal and altered sera.

\section{Discussion}

The Raman spectrum of serum in this study (Figure 2) presented features consistent with the Raman spectrum of glucose; the peaks at 507, 1065 and $1128 \mathrm{~cm}^{-1}$ were similar to those described by Bispo et al. (2013) where the peak of $1128 \mathrm{~cm}^{-1}$ in urine was a biomarker for diabetic and hypertensive patients. Intense peaks that can be related to lipids and lipoproteins have been found in serum at 877, 1004, 1271, 1307, 1343, 1451 and $1659 \mathrm{~cm}^{-1}$ 
(Barman et al., 2012; Berger et al., 1997; Berger et al., 1999; Dingari et al., 2011; Gremlich and Yan, 2001; Komachi et al., 2006; Krafft et al., 2005; Movasaghi et al., 2007; Shao et al., 2012; Silveira et al., 2012; Van de Poll et al., 2001). Differences in the concentrations of lipid and lipoprotein compounds in blood serum appear as differences in the peak intensities related to such compounds, as demonstrated by several quantitative studies (Berger et al., 1999; Qi and Berger, 2007; Rohleder et al., 2005; Shao et al., 2012).

Small differences in the Raman spectra of lipid components were found (Figures 3-6). These differences were related to the different concentrations of specific parameters. In particular, the difference spectra for cholesterol and triglycerides showed similar spectral features to cholesterol and saturated and unsaturated fatty acids, respectively. PCA and Euclidean distance could easily discriminate normal from altered groups for cholesterol and triglycerides. The composition of serum is complex; it contains $92-95 \%$ water, $4-8 \%$ proteins and peptides (mainly albumin), $0.4-0.8 \%$ total lipids, comprised of $0.02-0.3 \%$ triglycerides, $0.12-0.2 \%$ cholesterol, $(0.05-0.2 \%$ LDL and $0.03-0.09 \% \mathrm{HDL}), 0.1 \%$ glucose, and electrolytes, organic waste and a variety of other molecules in very small concentrations suspended or dissolved in it (Weatherby and Ferguson, 2004; Psychogios et al., 2011). The lipid fraction of the serum, together with glucose and cholesterol, accounts for less than $1 \%$ of the serum composition, with proteins the most abundant component (more than $80 \%$ of the dry serum is protein) (Weatherby and Ferguson, 2004). Thus the Raman bands of proteins, mainly albumin, dominate the spectrum and the small concentration of the other compounds mean their bands are difficult to observe. Even with this small concentration of lipid components and glucose in the serum, statistically significant differences in some peaks related to these compounds were observed in this study.

Principal components loading vectors showed peaks in the same positions of the main biochemicals of interest (glucose, cholesterol and triglycerides). Raman spectral features extracted from PCA have been used to reveal the differences in the biochemistry of normal and altered/pathological status of tissues and fluids, thus being able to discriminate histological groups of skin cancer in vitro (Bodanese et al., 2012) and in vivo (Silveira et al., 2015) and atherosclerosis in coronary arteries (Silveira et al., 2002), differential diagnosis in uveitis and endophthalmitis (Rossi et al., 2012), and detecting biomarkers for diseases in biological fluids such as serum and urine (Bispo et al., 2013; Saade et al., 2008). The loading vectors may be an important tool to show the differences in the biochemistry when the spectra of pure biochemicals cannot be obtained, and may present the same results in discrimination models using spectra of standard biochemicals (Bodanese et al., 2010).

According to the results presented in this work, the Raman technique is very promising for the analysis of biochemical parameters of blood serum. The technique has many advantages, such as rapid analysis, little or no sample preparation, use of small volumes of sample, detection of a wide array of parameters within a single spectrum, and no need for reagents. This study demonstrated the contribution that Raman spectroscopy may offer to the diagnosis of abnormalities in glucose and lipids in patients, thus helping in controlling the dyslipidemic and glycemic diseases in population screening, for instance. Investing in technologies for diagnosis would decrease the time and costs of population screening, while improving quality of life through early detection of alterations in the biochemical serum profile.

A method for quantification of blood serum components based on Raman spectroscopy may become, in the near future, an alternative to, or even replace existing methods for rapid serum biochemical analysis. The results presented here suggest that Raman spectroscopy could be a technique of choice for rapid and low-cost population screening for glucose, total cholesterol and triglycerides $(>70 \%$ discrimination capability), components of higher concentrations in human serum, that could be evaluated in a single measurement. Studies are underway to develop a model for a quantitative assay of these compounds, using their unique Raman spectral features.

\section{Acknowledgements}

L Silveira Jr. thanks FAPESP (São Paulo Research Foundation, Brazil) for the partial financial support (FAPESP Grant no. 2009/01788-5).

\section{References}

Aleixo GAS, Coelho MCOC, Guimarães ALN, Andrade MB, Silva JAA. Comparative evaluation between the portable glucometer and Trinders's enzymatic-colorimetric method to dose the glycemic values in dogs. Revista Portuguesa de Ciências Veterinárias. 2007; 102:(563-4): 351-54.

Bachorik PS, Denke MA, Stein EA, Rifkind BM. Lipids and dyslipoproteinemia. In: Henry JB, editor. Clinical diagnosis and management by laboratory methods. 20th ed. Philadelphia: W. B. Saunders; 2001. p. 224-48.

Barman I, Dingari NC, Kang JW, Horowitz GL, Dasari RR, Feld MS. Raman spectroscopy-based sensitive and specific detection of glycated hemoglobin. Analytical Chemistry. 2012; 84(5):2474-82. http://dx.doi.org/10.1021/ac203266a. PMid:22324826. 
Berger AJ, Itzkan I, Feld MS. Feasibility of measuring blood glucose concentration by near-infrared Raman spectroscopy. Spectrochimica Acta. Part A, Molecular and Biomolecular Spectroscopy. 1997; 53A(2):287-92. PMid:9097902.

Berger AJ, Koo T-W, Itzkan I, Horowitz G, Feld MS. Multicomponent blood analysis by near-infrared Raman spectroscopy. Applied Optics. 1999; 38(13):2916-26. http:// dx.doi.org/10.1364/AO.38.002916. PMid:18319874.

Bispo JAM, Sousa Vieira EE, Silveira L Jr, Fernandes AB. Correlating the amount of urea, creatinine, and glucose in urine from patients with diabetes mellitus and hypertension with the risk of developing renal lesions by means of Raman spectroscopy and principal component analysis. Journal of Biomedical Optics. 2013; 18(8):87004. http://dx.doi. org/10.1117/1.JBO.18.8.087004. PMid:23929457.

Bodanese B, Silveira L Jr, Albertini R, Zângaro RA, Pacheco MTT. Differentiating normal and basal cell carcinoma human skin tissues in vitro using dispersive Raman spectroscopy: a comparison between principal components analysis and simplified biochemical models. Photomedicine and Laser Surgery. 2010; 28(Suppl 1):S119-27. http://dx.doi. org/10.1089/pho.2009.2565. PMid:20649423.

Bodanese B, Silveira FL, Zângaro RA, Pacheco MTT, Pasqualucci CA, Silveira L Jr. Discrimination of basal cell carcinoma and melanoma from normal skin biopsies in vitro through Raman spectroscopy and principal component analysis. Photomedicine and Laser Surgery. 2012; 30(7):381-7. http://dx.doi.org/10.1089/pho.2011.3191. PMid:22693951.

Brasil. Ministério da Saúde. Secretaria de Atenção à Saúde. Departamento de Atenção Básica. Diabetes Mellitus cadernos de atenção básica. Brasília: Ministério da Saúde; 2006. (Cadernos de Atenção Básica, 16).

Buschman HP, Deinum G, Motz JT, Fitzmaurice M, Kramer JR, van der Laarse A, Bruschke AV, Feld MS. Raman microspectroscopy of human coronary atherosclerosis: biochemical assessment of cellular and extracellular morphologic structures in situ. Cardiovascular Pathology: The Official Journal of the Society for Cardiovascular Pathology. 2001; 10(2):69-82. http://dx.doi.org/10.1016/ S1054-8807(01)00064-3. PMid:11425600.

Carey PR. Biological and biochemical applications of Raman and resonance Raman spectroscopies. New York: Academic Press; 1982.

Ciaccio EJ, Dunn SM, Akay M. Biosignal pattern-recognition and interpretation systems. Part 3 of 4 . Methods of classification. IEEE Engineering in Medicine and Biology. 1994; 13(1):129-35. http://dx.doi.org/10.1109/51.265792.

Cordova CMM, Valle JP, Yamanaka CN, Cordova MM. Determination of capillary blood glucose and venous blood glucose with a glucometer versus laboratory determination of venous plasma glucose. Jornal Brasileiro de Patologia e Medicina Laboratorial. 2009; 45(5):379-84.

Dingari NC, Barman I, Singh GP, Kang JW, Dasari RR, Feld MS. Investigation of the specificity of Raman spectroscopy in non-invasive blood glucose measurements. Analytical and Bioanalytical Chemistry. 2011; 400(9):2871-80. http:// dx.doi.org/10.1007/s00216-011-5004-5. PMid:21509482.

Dingari NC, Horowitz GL, Kang JW, Dasari RR, Barman I. Raman spectroscopy provides a powerful diagnostic tool for accurate determination of albumin glycation. PLoS
One. 2012; 7(2):e32406. http://dx.doi.org/10.1371/journal. pone.0032406. PMid:22393405.

Dou X, Yamaguchi Y, Yamamoto H, Doi S, Ozaki Y. Quantitative analysis of metabolites in urine using a highly precise, compact near-infrared Raman spectrometer. Vibrational Spectroscopy. 1996; 13(1):83-9. http://dx.doi. org/10.1016/0924-2031(96)00036-7.

Fukuyama N, Homma K, Wakana N, Kudo K, Suyama A, Ohazama H, Tsuji C, Ishiwata K, Eguchi Y, Nakazawa $\mathrm{H}$, Tanaka E. Validation of the Friedewald equation for evaluation of plasma LDL-Cholesterol. Journal of Clinical Biochemistry and Nutrition. 2008; 43(1):1-5. http://dx.doi. org/10.3164/jcbn.2008036. PMid:18648653.

Gremlich HU, Yan B. Infrared and Raman spectroscopy of biological materials. New York: Marcel Dekker; 2001.

Grundy SM, Cleeman JI, Daniels SR, Donato KA, Eckel RH, Franklin BA, Gordon DJ, Krauss RM, Savage PJ, Smith SC Jr, Spertus JA, Costa F, American Heart Association, National Heart, Lung, Blood Institute. Diagnosis and management of the metabolic syndrome: an American Heart Association/National Heart, Lung, and Blood Institute Scientific Statement. Circulation. 2005; 112(17):2735-52. http://dx.doi.org/10.1161/CIRCULATIONAHA.105.169404. PMid:16157765.

Guimarães AE, Pacheco MTT, Silveira L Jr, Basottini D, Duarte J, Villaverde AB, Zângaro RA. Near Infrared Raman Spectroscopy (NIRS): A technique for doping control. Spectroscopy International Journal. 2006; 20(4):185-94. http://dx.doi.org/10.1155/2006/328210.

Hanlon EB, Manoharan R, Koo T-W, Shafer KE, Motz JT, Fitzmaurice M, Kramer JR, Itzkan I, Dasari RR, Feld MS. Prospects for in vivo Raman spectroscopy. Physics in Medicine and Biology. 2000; 45(2):R1-59. http://dx.doi. org/10.1088/0031-9155/45/2/201. PMid:10701500.

Hinkle JL, Cheever KH. Brunner \& Suddarth's textbook of medical surgical nursing. 13th ed. Philadelphia: Lippincott Willians \& Wilkins, 2013.

Klein R, Klein BEK, Lee KE, Cruickshanks KJ, Moss $\mathrm{SE}$. The incidence of hypertension in insulin-dependent diabetes. Archives of Internal Medicine. 1996; 156(6):622-7. http://dx.doi.org/10.1001/archinte.1996.00440060042005. PMid:8629873.

Knudson PE, Weinstock RS, Henry JB. Carbohydrates. In: Henry JB, editor. Clinical diagnosis and management by laboratory methods. 20th ed. Philadelphia: W. B. Saunders; 2001.

Komachi Y, Sato H, Tashiro H. Intravascular Raman spectroscopic catheter for molecular diagnosis of atherosclerotic coronary disease. Applied Optics. 2006; 45(30):7938-43. http://dx.doi.org/10.1364/AO.45.007938. PMid:17068531.

Krafft C, Neudert L, Simat T, Salzer R. Near infrared Raman spectra of human brain lipids. Spectrochimica Acta. Part A: Molecular and Biomolecular Spectroscopy. 2005; 61(7):1529-35. http://dx.doi.org/10.1016/j.saa.2004.11.017. PMid:15820887.

Lago RM, Singh PP, Nesto RW. Diabetes and hypertension. Nature Clinical Practice. Endocrinology \& Metabolism. 2007; 3(10):667. http://dx.doi.org/10.1038/ncpendmet0638. PMid:17893686. 
McMurdy JW 3rd, Berger AJ. Raman spectroscopy-based creatinine measurement in urine samples from a multipatient population. Applied Spectroscopy. 2003; 57(5):522-5. http:// dx.doi.org/10.1366/000370203321666533. PMid:14658677.

Movasaghi Z, Rehman S, Rehman I. Raman spectroscopy of biological tissues. Applied Spectroscopy Reviews 2007; 42(5):493-541. http://dx.doi.org/10.1080/05704920701551530.

National Cholesterol Education Program (NCEP) Expert Panel on Detection, Evaluation, Treatment of High Blood Cholesterol in Adults (Adult Treatment Panel III). Third report of the National Cholesterol Education Program (NCEP) expert panel on detection, evaluation, and treatment of high blood Cholesterol in adults (Adult Treatment Panel III) final report. Circulation 2002; 106(25):3143-421. PMid:12485966.

Psychogios N, Hau DD, Peng J, Guo AC, Mandal R, Bouatra S, Sinelnikov I, Krishnamurthy R, Eisner R, Gautam B, Young N, Xia J, Knox C, Dong E, Huang P, Hollander Z, Pedersen TL, Smith SR, Bamforth F, Greiner R, McManus B, Newman JW, Goodfriend T, Wishart DS. The human serum metabolome. PLoS One. 2011; 6(2):e16957. http:// dx.doi.org/10.1371/journal.pone.0016957. PMid:21359215.

Qi D, Berger AJ. Chemical concentration measurement in blood serum and urine samples using liquid-core optical fiber Raman spectroscopy. Applied Optics. 2007; 46(10):1726-34 http://dx.doi.org/10.1364/AO.46.001726. PMid:17356615.

Rohleder D, Kocherscheidt G, Gerber K, Kiefer W, Köhler W, Möcks J, Petrich W. Comparison of mid-infrared and Raman spectroscopy in the quantitative analysis of serum. Journal of Biomedical Optics. 2005; 10(3):031108. http:// dx.doi.org/10.1117/1.1911847. PMid:16229633.

Römer TJ, Brennan JF 3rd, Schut TC, Wolthuis R, van den Hoogen RCM, Emeis JJ, van der Laarse A, Bruschke AVG, Puppels GJ. Raman spectroscopy for quantifying cholesterol in intact coronary artery wall. Atherosclerosis. 1998; 141(1):117-24. http://dx.doi.org/10.1016/S00219150(98)00155-5. PMid:9863544.

Rossi EE, Pinheiro ALB, Baltatu OC, Pacheco MTT, Silveira L Jr. Differential diagnosis between experimental endophthalmitis and uveitis in vitreous with Raman spectroscopy and principal components analysis. Journal of Photochemistry and Photobiology. B, Biology. 2012; 107:73-8. http://dx.doi.org/10.1016/j.jphotobiol.2011.12.001. PMid:22209031.

Saade J, Pacheco MTT, Rodrigues MR, Silveira L Jr. Identification of hepatitis $\mathrm{C}$ in human blood serum by near-infrared Raman spectroscopy. Spectroscopy International Journal. 2008; 22(5):387-95. http://dx.doi. org $/ 10.1155 / 2008 / 419783$.

Saade J, Silva JN, Farias PMA, Lopes DF, Santos CT, Farias BA, Rodrigues KC, Martin AA. Glicemical analysis of human blood serum using FT-Raman: a new approach. Photomedicine and Laser Surgery. 2012; 30(7):388-92. http://dx.doi.org/10.1089/pho.2012.3238. PMid:22694727.

Shao J, Lin M, Li Y, Li X, Liu J, Liang J, Yao H. In vivo blood glucose quantification using Raman spectroscopy. PLoS One. 2012; 7(10):e48127. http://dx.doi.org/10.1371/ journal.pone.0048127. PMid:23133555.

Silveira L Jr, Sathaiah S, Zângaro RA, Pacheco MTT, Chavantes MC, Pasqualucci CAG. Correlation between near-infrared Raman spectroscopy and the histopathological analysis of atherosclerosis in human coronary arteries. Lasers in Surgery and Medicine. 2002; 30(4):290-7. http://dx.doi. org/10.1002/1sm.10053. PMid:11948599.

Silveira L Jr, Silveira FL, Bodanese B, Zângaro RA, Pacheco MTT. Discriminating model for diagnosis of basal cell carcinoma and melanoma in vitro based on the Raman spectra of selected biochemicals. Journal of Biomedical Optics. 2012; 17(7):077003. http://dx.doi.org/10.1117/1. JBO.17.7.077003. PMid:22894516.

Silveira FL, Pacheco MTT, Bodanese B, Pasqualucci CA, Zângaro RA, Silveira L Jr. Discrimination of non-melanoma skin lesions from non-tumor human skin tissues in vivo using Raman spectroscopy and multivariate statistics. Lasers in Surgery and Medicine. 2015; 47(1):6-16. http://dx.doi. org/10.1002/lsm.22318. PMid:25583686.

Stone NJ, Robinson JG, Lichtenstein AH, Bairey Merz CN, Lloyd-Jones DM, Blum CB, Eckel RH, Goldberg AC, Gordon D, Levy D, Lloyd-Jones DM, McBride P, Schwartz JS, Shero ST, Smith SC Jr, Watson K, Wilson PW. 2013 ACC/AHA guideline on the treatment of blood cholesterol to reduce atherosclerotic cardiovascular risk in adults: a report of the American College of Cardiology/American Heart Association Task Force on Practice Guidelines. Journal of the American College of Cardiology. 2013; 63(25 Pt B):2889-934. PMid:24239923.

Twardowski J, Anzenbacher P. Raman and IR spectroscopy in biology and biochemistry. New York: Ellis Horwood; 1994.

Van de Poll SWE, Römer TJ, Volger OL, Delsing DJM, Bakker Schut TC, Princen HMG, Havekes LM, Jukema JW, van Der Laarse A, Puppels GJ. Raman spectroscopic evaluation of the effects of diet and lipid-lowering therapy on atherosclerotic plaque development in mice. Arteriosclerosis, Thrombosis, and Vascular Biology. 2001; 21(10):1630-5. http://dx.doi.org/10.1161/hq1001.096651. PMid:11597937.

Wannamethee SG, Shaper AG, Lennon L, Morris RW. Metabolic syndrome vs Framingham Risk Score for prediction of coronary heart disease, stroke, and type 2 diabetes mellitus. Archives of Internal Medicine. 2005; 165(22):2644-50. http:// dx.doi.org/10.1001/archinte.165.22.2644. PMid:16344423.

Weatherby D, Ferguson S. Blood chemistry and CBC analysis. Bloomfield: Weatherby \& Associates; 2004.

\section{Authors}

Rita de Cássia Fernandes Borges ${ }^{1}$, Ricardo Scarparo Navarro ${ }^{1}$, Hector Enrique Giana ${ }^{2}$, Fernanda Grubisich Tavares ${ }^{2}$, Adriana Barrinha Fernandes ${ }^{1}$, Landulfo Silveira Junior ${ }^{1 *}$

${ }^{1}$ Biomedical Engineering Institute, Universidade Camilo Castelo Branco - Unicastelo, Parque Tecnológico de São José dos Campos, Estr. Dr. Altino Bondesan, 500, CEP 12247-016, São José dos Campos, SP, Brazil.

${ }^{2}$ Laboratório de Análises Clínicas Oswaldo Cruz, Praça Cândida Maria Cesar Sawaya Giana, 128, CEP 12243-003, Jardim Nova América, São José dos Campos, SP, Brazil. 